\title{
Biomass flow in Tifton-85 bermudagrass canopy subjected to different management strategies under rotational grazing with dairy goats ${ }^{1}$
}

\author{
José Antonio Alves Cutrim Junior ${ }^{2}$, Ana Clara Rodrigues Cavalcante ${ }^{3}$, Magno José Duarte \\ Cândido $^{4}$, Gutenberg Lira Silva ${ }^{5}$, Luiza Elvira Vieira Oliveira ${ }^{5}$, Elayne Cristina Gadelha \\ Vasconcelos $^{5}$, Tony Maiko Oliveira Mesquita ${ }^{5}$
}

\author{
${ }^{1}$ Funded by BNB; EMBRAPA Macroprogram 3. \\ 2 Programa de Doutorado Integrado PDIZ-UFC. FUNCAP fellow student. Instituto Federal Maranhão - IFMA, Campus São Luis-Maracanã. \\ ${ }^{3}$ Embrapa Caprinos e Ovinos, Sobral-CE, Brazil. \\ ${ }^{4}$ Departamento de Zootecnia - UFC, Fortaleza-CE, Brazil. CNPq Researcher. \\ ${ }^{5}$ Graduando do Curso de Zootecnia da Universidade Estadual Vale do Acaraú - UVA, Sobral-CE, Brazil.
}

\begin{abstract}
Biomass flow characteristics and forage accumulation were evaluated in Bermudagrass (Tifton 85) pasture managed under intermittent stocking with different management strategies. The management levels utilized were conventional (10 cm residual height and unfertilized), light $(20 \mathrm{~cm}$ residual height and unfertilized), moderate $(20 \mathrm{~cm}$ residual height with fertilization of $300 \mathrm{~kg} \mathrm{~N} /$ ha.year) and intensive (10 cm residual height with fertilization of $600 \mathrm{~kg} \mathrm{~N} / \mathrm{ha} . y e a r)$. A randomized design was used with repeated measurements over time, in two periods of the year, with four replicates. There was significant effect of management $\times$ period of the year on the leaf elongation rate (LER). The management levels under fertilization $(0.59$ and $0.60 \mathrm{~cm} /$ tiller.day for the intensive and moderate management, respectively) and the rainy season $(0.49 \mathrm{~cm} /$ tiller.day) showed the greatest stem elongation rate. Leaf senescence rate (LSR) before and after and total LSR were modified by the management $\times$ period of the year interaction. The intensive management, with 0.38 leaves/tiller. day, as well as the dry period, with 0.27 leaves/tiller.day, showed higher leaf appearance rate. The lowest phyllochron was observed in intensive management and dry periods, as well as an interaction with the management of the same periods of the year. There was management $\times$ period of year interaction effect on leaf lifespan; the highest value was found under conventional management and dry period. Both production and forage accumulation rates were higher in the intensive and moderate management levels and dry season, and there was interaction of the intensive management system with the seasons. Managing pastures under moderate and intensive rotational stocking, which occurred mainly in the rainy and dry seasons, respectively, maximizes the flow of tissues and consequently production and accumulation of forage.
\end{abstract}

Key Words: Cynodon spp., dairy goat, morphogenesis, pasture management

\section{Introduction}

Morphogenesis in a tropical pasture in vegetative growth can be described by four basic characteristics: stem elongation rate, leaf appearance and elongation rates and leaf lifespan (Chapman \& Lemaire, 1993; Candido, 2003). These characteristics are genetically determined, but influenced by environmental variables such as temperature, water availability and nutrients, which vary widely throughout the year, in addition to grazing management, given by the constant adjustment of the intensity and frequency of defoliation, aiming at better pasture use efficiency (Lemaire \& Chapman, 1996).

The use of nutrients through pasture fertilization is an strategy of pasture management intensification, which clearly aims at productivity increase. It is possible to increase the pasture stocking rate and the animal production per unit area (Moreira, 2000), making it unnecessary to open new agricultural frontiers, especially in naturally virgin areas, more susceptible to the process of degradation, to increase animal production in Brazil.

Pasture fertilization results in increased flow of forage plant tissues, which comes to be characterized by increased rates of leaf appearance and leaf and stem elongation. Thus, there are more intense variations per unit of time in the structural characteristics of the fertilized pasture, which requires modifying the actions of grazing management for the structure. In fertilized pastures it is essential that actions of grazing management be used differently from non-fertilized systems. This is because the use of fertilizers, depending on the level, changes the processes intrinsic to the soil-plant-animal system, such as plant development 
per time unit, which includes the processes of growth and senescence (Santos, 2010).

In fertilized pastures, there is the possibility of increasing the grazing intensity. The higher the grazing intensity, characterized by lower height of residue after grazing (rotational stocking) or reduced average pasture height (continuous stocking), the greater the percentage of forage removed from pasture and therefore, the fewer the nutrients to be recycled in the soil-plant system. Thus, less organic material returns to the ground, since the senescence process of plant tissue tends to be minimized. Therefore, larger amounts of fertilizer should be applied to the pasture to ensure its continuity and sustainability. The decrease in light interception and photosynthetic capacity of the plant, the reduction in the levels of nitrogen reservations and transfer time of nitrogen from the roots and stem base to the new leaf and the lower growth of roots are factors that explain the greater demand for nutrients by the plant at higher defoliation intensities (Martha Junior et al., 2007).

According to Da Silva (2004), it is appropriate to adopt less intensive defoliation in plants under conditions of less fertile soils and limited use of fertilizers compared with those that vegetate in more fertile soils and/or receive appropriate supply of nutrients via fertilization, simply because a plant cannot vegetate and grow properly without exhausting the soil and thus initiating the degradation process.

Besides nutrients, climate condition is also important for the high increment of forage mass over the year. The speed of pasture recovery after defoliation depends on edaphoclimatic factors prevailing at a given time. Fluctuations in weather conditions, resulting in temperature and water stress, alter the morphology and the rate of plant development by limiting its production and altering the nutritional value of forage produced (Buxton \& Fales, 1994).

In growth seasons that occur in favorable weather conditions (temperature, radiation and water availability), the speed of pasture recovery is faster, reducing intervals between grazing sessions and thus increasing the number of grazing cycles in Tanzania grass pastures (Barbosa et al., 2007). According to Uebele (2002), the practical inference of these results is simple, i.e., grazing management strategies based on fixed rest periods are potentially dangerous and can result in significant loss of production and nutritional value of the forage produced.

Therefore, the objective of this study was to evaluate the dynamics of biomass flow in Tifton 85 canopy under rotational stocking with different management strategies throughout the year.

\section{Material and Methods}

The research was conducted at the Centro de Produção de Caprinos Leiteiros, Embrapa Caprinos e Ovinos, located in the municipality of Sobral-CE, $70 \mathrm{~m}$ altitude, $3^{\circ} 44^{\prime} 58^{\prime \prime}$ south longitude and $40^{\circ} 20^{\prime} 42^{\prime \prime}$ west latitude. The experimental period was from February 2009 to February 2010.

The experimental area consisted of 1.5 ha of Tifton 85 pasture, deployed since 2008 in the area of Caatinga, previously subdivided into 44 paddocks, irrigated under lowpressure spray divided into two sectors. The irrigation was performed according to the reference evapotranspiration $\left(\mathrm{ET}_{0}\right)$ in the region of Sobral corrected by FAOPenmanMonteith (Cabral, 2000), varying from month to month. An application efficiency of $70 \%$ was considered so that the average precipitation of the sprinklers was $3.93 \mathrm{~mm} /$ hour with every-day irrigation due to the physical characteristics of the soil (soil with rock plates in the first few layers), whose depth is less than $30 \mathrm{~cm}$.

The soil in the area is classified as predominantly Luvisol (Santos et al., 2006). In order to correct the deficiencies presented (Table 2), as well as to provide better initial development of the pasture, fertilization for correction was applied throughout the area with $150 \mathrm{~kg}$ urea, $212 \mathrm{~kg}$ triple superphosphate, $302 \mathrm{~kg}$ potassium chloride and $50 \mathrm{~kg}$ FTE BR-12 per hectare (CFSEMG, 1999). This application was

Table 1 - Climatic characteristics of the experimental setting monthly from February 2009 to February 2010

\begin{tabular}{|c|c|c|c|c|c|c|c|c|c|c|c|c|c|}
\hline \multirow{2}{*}{ Variables } & \multicolumn{11}{|c|}{ Months-2009 } & \multicolumn{2}{|c|}{ Months-2010 } \\
\hline & Feb & Mar & Apr & May & Jun & Jul & Aug & Sep & Oct & Nov & Dec & Jan & Feb \\
\hline $\operatorname{Max} T$ & 31.9 & 31.0 & 30.6 & 30.3 & 30.5 & 31.5 & 34.6 & 36.3 & 36.7 & 36.2 & 36.6 & 36.4 & 34.6 \\
\hline $\operatorname{Min} T$ & 22.7 & 22.9 & 22.8 & 22.5 & 21.3 & 20.9 & 20.5 & 21.6 & 21.3 & 21.9 & 22.6 & 23.0 & 23.2 \\
\hline $\operatorname{Avg} \mathrm{T}$ & 25.8 & 25.9 & 26.2 & 25.4 & 26.3 & 24.4 & 27.9 & 30.3 & 27.9 & 30.0 & 28.6 & 27.6 & 29.0 \\
\hline $\mathrm{RH}(\%)$ & 75.0 & 78.0 & 85.0 & 85.0 & 81.0 & 83.0 & 61.0 & 54.0 & 54.0 & 52.0 & 56.0 & 61.0 & 68.0 \\
\hline WS (m/s) & 1.30 & 1.20 & 1.10 & 0.80 & 1.00 & 0.6 & 1.90 & 2.90 & 2.40 & 2.90 & 3.40 & 3.30 & 1.80 \\
\hline Nebulosity ${ }^{1}$ & 7.00 & 7.40 & 7.90 & 7.50 & 5.30 & 5.50 & 3.50 & 3.20 & 4.20 & 3.80 & 4.20 & 5.00 & 6.20 \\
\hline Prec.(mm) & 133.3 & 398.4 & 242.0 & 215.0 & 36.0 & 0.00 & 0.00 & 0.00 & 0.00 & 0.00 & 0.00 & 121.1 & 77.4 \\
\hline $\mathrm{ET}_{0}(\mathrm{~mm})$ & 116.0 & 125.0 & 115.0 & 102.0 & 102.0 & 92.0 & 109.0 & 126.0 & 136.0 & 126.0 & 138.0 & 135.0 & 122.0 \\
\hline
\end{tabular}

Max T - maximum temperature; Min T - minimum temperature; Avg T - average temperature; RH - relative humidity; WS - wind speed; Prec. - precipitation; ET0 - accumulated reference evapotranspiration.

${ }^{1}$ Ranging from 1 to 10 , where 1 is cloudless sky and 10 is completely overcast sky. 
fractionated into two, three months before the experiment began, across the area. Because $\mathrm{pH}$ and base saturation (BS\%) presented mean values of 5.3 and $80 \%$, respectively, no correction for soil acidity was necessary.

Different pasture management levels were evaluated: conventional (10 $\mathrm{cm}$ residual height and unfertilized), light $(20 \mathrm{~cm}$ residual height and unfertilized) moderate $(20 \mathrm{~cm}$ residual height and fertilization equivalent to $300 \mathrm{~kg} \mathrm{~N} / \mathrm{ha}$ year) and intensive (10 $\mathrm{cm}$ residual height and fertilization equivalent to $600 \mathrm{~kg} \mathrm{~N} /$ ha year). The residual height of 5 and $10 \mathrm{~cm}$ previously advocated was reset because the grazing habit of goats did not promote lowering of pastures to such heights. A completely randomized design with repeated measures, seasons (wet and dry) and four replications (plots) was evaluated. The evaluations were conducted in two seasons: rainy and dry, established according to the rainfall throughout the year. The rainy season comprised grazing cycles from February to June 2009 and the dry season under irrigation corresponded to the grazing cycles from July 2009 to January 2010.

Fertilization maintenance consisted of applying only nitrogen in the form of urea to the intensive and moderate management distributed throughout the year, according to the estimated number of grazing cycles, with this amount adjusted according to the estimate number of grazing cycles (10.0, 10.9, 15.0 and 16.5 cycles/year for conventional, light, moderate and intensive management, respectively). During the rest interval, within the grazing cycle, nitrogen fertilization was fractionated into two applications: the first was performed one day after the removal of animals and the second about halfway through the rest period. In order to minimize losses by volatilization, the application occurred in the first hours of the morning.

The grazing method in rotational stocking with variable stocking rate was adopted. Dairy goats of AngloNubian and Saanen breeds under lactation were used as test animals. Goats were conducted to the paddocks when the canopy was at pre-grazing condition and kept for four days on pasture in each paddock in order to ensure the lowering of vegetation to the residual height established for each management. Non-lactating goats were used as regulation animals, conducted to paddocks whenever necessary for lowering the vegetation to the residual height of each management.

As a criterion for entry of animals in the paddocks the level of $95 \%$ interception of photosynthetically active radiation (IPAR) was used, ranging from $0.5 \%$ above or below this value, obtained through the analyzer PAR/LAI in Agriculture DECAGON-LP 80 (DECAGON ${ }^{\circledR}$ Devices, Inc., Pullman, Washington, USA). Thus, 15 points at locations representative of the average condition of the paddock are sampled and then the average light interception at each paddock is obtained. When the canopy reached $95 \%$ of light interception, pasture heights were 29.9, 29.2, 30.1 and $35.3 \mathrm{~cm}$ in the conventional intensive, light and moderate management levels, respectively.

Four experimental plots were used per management, and the remaining paddocks served to allow the appropriate pasture rest to reach the level of light interception recommended for entry of animals. All paddocks had dimension of $15.4 \times$ $14.1 \mathrm{~m}$ (approximately $217.2 \mathrm{~m}^{2}$ each), surrounded with farm fence mesh and provided with shade cloth of $10 \mathrm{~m}^{2}$ with $25 \%$ transparency, drinkers and salt troughs.

Two points were marked on the experimental plots with iron rods after animals left, changing them at every new grazing cycle. At each point, three tillers were randomly identified with colored rings of phone wire with ribbons of the same color, tied to facilitate their location. In those tillers, the total length of fully expanded leaves, emerging leaves and stem height were recorded two days after animals leaft and every four days. The length of the fully expanded leaves was measured by the distance from their ligule to the leaf apex. Emerging leaf blade length was obtained by measuring the distance from the apex of that leaf to the previous expanded leaf ligule. Stem length was obtained by measuring the distance from the last exposed ligule to the base of the tiller (Candido et al., 2006; Cutrim Junior et al., 2010).

Table 2 - Soil fertility analysis of the experimental area for correction

\begin{tabular}{|c|c|c|c|c|c|c|c|c|c|}
\hline Depth (m) & Side $^{1}$ & $\begin{array}{c}\mathrm{pH} \\
\text { (water) }\end{array}$ & $\begin{array}{c}\mathrm{OM} \\
\mathrm{g} / \mathrm{dm}^{3}\end{array}$ & $\begin{array}{l}\text { BS } \\
(\%)\end{array}$ & $\begin{array}{c}\mathrm{P} \\
\mathrm{mg} / \mathrm{dm}^{3}\end{array}$ & $\begin{array}{c}\mathrm{Cu} \\
\mathrm{mg} / \mathrm{dm}^{3}\end{array}$ & $\begin{array}{c}\mathrm{Fe} \\
\mathrm{mg} / \mathrm{dm}^{3}\end{array}$ & $\begin{array}{c}\mathrm{Mn} \\
\mathrm{mg} / \mathrm{dm}^{3}\end{array}$ & $\begin{array}{c}\mathrm{Zn} \\
\mathrm{mg} / \mathrm{dm}^{3}\end{array}$ \\
\hline \multirow{5}{*}{$0.0-0.20$} & Right & 5.4 & 14.9 & 78 & 7.0 & 0.6 & 176.0 & 44.8 & 6.3 \\
\hline & Left & 5.2 & 15.4 & 82 & 7.0 & 0.8 & 251.0 & 32.2 & 3.5 \\
\hline & & $\begin{array}{c}\mathrm{K} \\
\mathrm{mmolc} / \mathrm{dm}^{3}\end{array}$ & $\begin{array}{c}\mathrm{Ca} \\
\mathrm{mmolc} / \mathrm{dm}^{3}\end{array}$ & $\begin{array}{c}\mathrm{Mg} \\
\mathrm{mmolc} / \mathrm{dm}^{3}\end{array}$ & $\begin{array}{c}\mathrm{Al} \\
\mathrm{mmolc} / \mathrm{dm}^{3}\end{array}$ & $\begin{array}{c}\mathrm{H}+\mathrm{Al} \\
\mathrm{mmolc} / \mathrm{dm}^{3}\end{array}$ & $\begin{array}{c}\mathrm{SB} \\
\mathrm{mmolc} / \mathrm{dm}^{3}\end{array}$ & $\begin{array}{c}\mathrm{CEC} \\
\mathrm{mmolc} / \mathrm{dm}^{3}\end{array}$ & $\begin{array}{c}\mathrm{Na} \\
\mathrm{mmolc} / \mathrm{dm}^{3}\end{array}$ \\
\hline & Right & 2.2 & 43.0 & 19.0 & $<1$ & 18.8 & 64.5 & 83.1 & 0.8 \\
\hline & Left & 2.2 & 51.0 & 44.0 & $<1$ & 22.2 & 99.0 & 121 & 1.5 \\
\hline
\end{tabular}

OM - organic matter; SB - sum of bases; CEC - cation exchange capacity; BS - base saturation.

${ }^{1}$ The total area was divided into two sides to facilitate sampling. 
The tiller population density (TPD) was estimated in two stages. The residual TPD was estimated five days after animals leaft the paddocks, by counting the number of live tillers within three $0.25 \times 0.25 \mathrm{~m}$ frames. The pre-grazing TDP was estimated one day before animals entered the paddocks, by counting the number of live tillers within two $0.50 \times 0.50 \mathrm{~m}$ frames representing the average condition of the pasture. The TDP was calculated as the mean of values obtained post- and pre-grazing.

Using length measurements of leaf blades, stems, and number of green leaves/tiller, the following indices were estimated: a) leaf elongation rate (LER) (average daily elongation of leaf blades of tillers during the rest period); $b$ ) stem elongation rate (SER) (average daily stem elongation of tillers during the rest period); c) ratio between the leaf elongation rates on the first and second leaf produced at the beginning of each tiller regrowth $\left(\mathrm{LER}_{1} / \mathrm{LER}_{2}\right)$, which indicates greater pasture vigor when the $\mathrm{LER}_{1} / \mathrm{LER}_{2}$ ratio is closer to 1.0, i.e., when the elongation of the first leaf is compromised by mobilization of organic reserves, a situation in which growth restarts more slowly (Candido et al., 2006); d) Leaf senescence rate formed prior to grazing and remnants (LSRp) and leaf senescence rate after grazing (LSRa); e) Total leaf senescence rate (TSR), representing the sum of LSRp with LSRa; f) leaf appearance rate (LAR), which determines the speed of leaf emergence on the tiller, measured by the number of leaves produced in a given interval of days; g) Phyllochron, expressing the time in days, needed for full leaf expansion, i.e., so that the leaf reaches its final length, characterized by the ligule exposure; and h) leaf lifespan (LLT), obtained by multiplying the number of green leaves/tiller and phyllochron.

Gravimetric indices were determined for the production of stem, emerging leaf blades and their senescence. Therefore, at the end of each rest period approximately 40 tillers were collected per sampling paddock; these tillers were taken to the laboratory and separated into stems, expanded leaf blades and emerging leaf blades. Each of these fractions had its total length recorded and were dried in a forced-ventilation oven at $65{ }^{\circ} \mathrm{C}$ until constant weight for obtaining the index of weight per length unit of the emerging leaf blade (a1), expanded leaf blade (a2) and stems (b).

Forage production rates (FPR) and forage accumulation rates (FAR) were calculated by the agronomic method, using the dry masses of pre-grazing and residual forage, estimated according to the equations:

$$
\begin{aligned}
\text { FPRi } & =(\text { TFDMi }- \text { THDMri }) \div \mathrm{RPi} \\
\text { FARi } & =(\text { GFDMi }- \text { GHDMri }) \div R P i
\end{aligned}
$$

where: $\mathrm{FPRi}=$ forage production rate during the rest period $\mathrm{i}(\mathrm{kg} \mathrm{DM} /$ ha.day); FARi = forage accumulation rate during the rest period $\mathrm{i}(\mathrm{kg} \mathrm{DM} /$ ha.day); TFDMi = pre-grazing total forage dry matter of cycle $\mathrm{i}(\mathrm{kg} / \mathrm{ha})$; TFDMri $=$ total residual forage dry matter of cycle $\mathrm{i}(\mathrm{kg} / \mathrm{ha})$; GFDMi $=$ pregrazing green forage dry mass of cycle $\mathrm{i}(\mathrm{kg} / \mathrm{ha})$; GFDMri = residual green forage dry mass of cycle $\mathrm{i}(\mathrm{kg} / \mathrm{ha}), \mathrm{RPi}=$ rest period of cycle i (days).

Data were analyzed by analysis of variance and means comparison test. To compare the effect of management and periods of the year, analysis of variance was performed with the average of all cycles occurring within the same period of the year and throughout the experiment, deploying the interaction when significant at 5\% probability. Means were compared using Tukey's test at 5\% probability. As a tool to aid these statistical analyses, the MIXED procedure of statistical software SAS (Statistical Analysis System, version 9.3.1) was used.

\section{Results and Discussion}

The management levels $(\mathrm{P}>0.05)$, periods of the year $(\mathrm{P}>0.05)$, and the interaction between these two factors did not influence the ratio between elongation rate of the first and second leaves formed in regrowth $\left(\mathrm{LER}_{1} / \mathrm{LER}_{2}\right)$. Among the management levels, the mean ranged between 0.72 and 0.83 and, in the periods of the year it was 0.80 in the rainy season and 0.77 in the dry season under irrigation. Such values may indicate a suitable pasture management since values closest to 1.0 indicate greater regrowth force of the forage plant, wherein the elongation of the first leaf blade is not compromised by the mobilization of body reserves, a situation in which growth occurs more slowly. Even at management levels with higher height, LER $_{1} / \mathrm{LER}_{2}$ behaved in a positive manner, since there is greater residual leaf area index in these pastures (rLAI of 0.91, 0.98, 1.70 and 1.81 for conventional, intensive, light and moderate management intensities, respectively), which promotes greater shading of lower leaves in the canopy due to the higher amount of leaves remaining after grazing, compromising the elongation of the first leaf produced in regrowth, due to decrease in photosynthetic potential of this leaf primordium still within the sheaths at the end of the rest period prior to and during grazing (Woledge, 1973; Woledge, 1977).

The leaf elongation rate (LER) was influenced by the interaction between the management levels and periods of the year $(\mathrm{P}<0.05)$ (Table 3$)$. There was a higher LER for intensive $(4.46 \mathrm{~cm} /$ tiller.day) and moderate $(3.85 \mathrm{~cm} /$ tiller.day, Table 3) management. This is due to the nitrogen fertilization that occurred in these management levels, as the effect of this nutrient in the plant occurs in the elongation zone (meristem interim), an active site with high nutrient 
requirement (Skinner \& Nelson, 1995). In the zone of cell division there is greater $\mathrm{N}$ accumulation (Gastal \& Nelson, 1994) and therefore this nutrient markedly affects the LER by increasing the number of cells. Little $\mathrm{N}$ is deposited outside the elongation zone of leaves, indicating that the Rubisco synthesis is dependent on this $\mathrm{N}$ accumulation in the area of cell division, i.e., the photosynthetic potential of the plant is determined at the beginning of the leaf elongation period. Therefore, $\mathrm{N}$ deficits may compromise future photosynthetic efficiency (Skinner \& Nelson, 1995). It was observed that among the management levels without fertilization, conventional management showed higher LER with greater pasture intensity, compared with the light management in the rainy season. Even with a shorter residual height, the rLAI was possibly minimally adjusted to ensure high photosynthesis of remnant leaves and even those at the lower part of the canopy, providing large fixation of carbohydrates and favoring leaf elongation. In the light management, the pasture residual height may have been the greatest cause of diminished photosynthesis of remaining leaves on the canopy base affecting regrowth (Gomide et al., 2002; Braga et al., 2009).

There was reduction in the LER of management types without fertilization (conventional and light) from the rainy season to the dry season under irrigation (Table 3). This fact probably resulted from the shorter photoperiod (Table 1) in the rainy season. In low light environment, characterized by more cloudiness, the leaves tend to increase the leaf area to maximize light collection and perform their metabolic actions, unlike leaves that grow in a brighter environment, where they are usually smaller, but thicker, characterized by stacking of thylakoids in chloroplasts (Castro et al., 1999) to better exploit the whole reducing power generated in the photochemical phase of photosynthesis.
This was not observed in management intensities under fertilization (intensive and moderate) due to the great sensitivity of biomass flow to the constant nitrogen fertilization effect throughout the year, keeping this constant elongation even under conditions of greater cloudiness.

There was no effect of management $(\mathrm{P}<0.05)$ and periods of the year $(\mathrm{P}<0.05)$ on stem elongation rate (SER). There was higher SER for the management intensities with fertilization (intensive and moderate) compared with those unfertilized (conventional and light) (Table 3), demonstrating the strong nitrogen effect on stem elongation in tropical pastures. Comparing only the nonfertilized management levels, there was higher SER for the conventional management. The residual height was determinant for that since the light management had residual height of $21.7 \mathrm{~cm}$, unlike the $11.7 \mathrm{~cm}$ from conventional management. In the light management, pasture was at a stabilized residual height without major variations over time, where the leaf blade remained at a higher horizon and with high light availability, unlike the pasture in the conventional management, whose stem elongation was more pronounced at each new grazing cycle, given that increasing blade (LER of $2.92 \mathrm{~cm} /$ tiller.day, higher than $2.03 \mathrm{~cm} /$ tiller.day of light management) provided greater canopy shading throughout its development further decreasing the light incidence at the tiller base, also changing its light quality, decreasing the red/far red ratio of the intercepted photosynthetically active radiation (Deregibus et al., 1985). After being detected by the plant through the phytochrome system (Taiz \& Zaiger, 2004), this event triggers the process of stems elongation (Davis \& Simmons, 1994).

According to Bullock (1996), when there is rapid growth due to the large amount of fertilizer applied, tillers

Table 3 - Ratio between the elongation rates of leaf 1 and leaf $2\left(\mathrm{LER}_{1} / \mathrm{LER}_{2}\right)$, leaf elongation rate and stem elongation rate in Tifton 85 bermudagrass pastures under rotational stocking with different management strategies

\begin{tabular}{|c|c|c|c|c|c|c|c|}
\hline \multirow{2}{*}{ Variables } & \multirow{2}{*}{$\begin{array}{c}\text { Periods of the } \\
\text { year }\end{array}$} & \multicolumn{4}{|c|}{ Managements } & \multirow{2}{*}{ Mean } & \multirow{2}{*}{$\mathrm{CV}(\%)$} \\
\hline & & Conventional & Intensive & Light & Moderate & & \\
\hline \multirow{2}{*}{$\mathrm{LER}_{1} / \mathrm{LER}_{2}$} & Rainy & 0.82 & 0.80 & 0.81 & 0.77 & 0.80 & \multirow[t]{2}{*}{12.4} \\
\hline & Dry & 0.84 & 0.64 & 0.81 & 0.78 & 0.77 & \\
\hline Mean & & 0.83 & 0.72 & 0.81 & 0.77 & & \\
\hline \multirow{2}{*}{$\begin{array}{l}\text { Leaf elongation rate } \\
(\mathrm{cm} / \text { tiller.day) }\end{array}$} & Rainy & $3.58 \mathrm{Ab}$ & $4.70 \mathrm{Aa}$ & $2.52 \mathrm{Ac}$ & $4.00 \mathrm{Aab}$ & 3.70 & \multirow[t]{2}{*}{33.0} \\
\hline & Dry & $2.27 \mathrm{Bbc}$ & $4.23 \mathrm{Aa}$ & $1.54 \mathrm{Bc}$ & $3.72 \mathrm{Aa}$ & 2.94 & \\
\hline Mean & & 2.92 & 4.46 & 2.03 & 3.85 & & \\
\hline \multirow{2}{*}{$\begin{array}{l}\text { Stem elongation rate } \\
(\mathrm{cm} / \text { tiller.day) }\end{array}$} & Rainy & 0.42 & 0.62 & 0.29 & 0.64 & $0.49 \mathrm{~A}$ & \multirow[t]{2}{*}{40.8} \\
\hline & Dry & 0.27 & 0.57 & 0.17 & 0.56 & $0.39 \mathrm{~B}$ & \\
\hline Mean & & $0.34 b$ & $0.60 \mathrm{a}$ & $0.23 \mathrm{c}$ & $0.60 \mathrm{a}$ & & \\
\hline
\end{tabular}

$\overline{\mathrm{CV}}$ - coefficient of variation.

Managements: Conventional - $10 \mathrm{~cm}$ residual height and no fertilization; Intensive - $10 \mathrm{~cm}$ residual height and $600 \mathrm{~kg}$ N/ha.year; Light - $20 \mathrm{~cm}$ residual height and no fertilization; Moderate $-20 \mathrm{~cm}$ residual height and $300 \mathrm{~kg}$ of N/ha.year.

Means followed by the same uppercase letters in columns or lowercase letters in rows do not differ significantly (P $>0.05)$ by Tukey's test. 
become large by stem elongation, which has the greatest effect on pasture height. This elongation of stems, with strong carbon allocation in support structures is carried out in order to place the youngest leaves at the top of the canopy to capture the incident light.

Greater SER in canopies of tropical grasses promotes low leaf/stem ratio and, consequently, reduction in forage quality perceived by the animal (Candido et al., 2006; Pompeu et al., 2010). In this case, the largest fertilization performed in the intensive management contributed to a higher leaf/stem ratio, (0.74) compared with conventional (0.610), light (0.51) and moderate (0.57) management, demonstrating that the high amount of accumulated leaf blade in the canopy (high LER) possibly contributed to a pasture with better structure.

The SER in the rainy season was $0.49 \mathrm{~cm} /$ tiller.day, higher than $0.39 \mathrm{~cm} /$ tiller.day in the dry season under irrigation. The higher incidence of clouds (high number of clouds, which promotes greater amount of scattered light relative to direct light; Table 1) in the rainy season was largely responsible for the greater elongation of stems in that period.

There was effect of the interaction between management levels and periods of the year $(\mathrm{P}<0.05)$ on the leaf senescence rate before the expansion of the first leaf produced in the regrowth (LSRp). The conventional management had the lowest LSRp, with $0.69 \mathrm{~cm} /$ tiller.day in the rainy season and consequently among all management levels (Table 4). This response pattern was expected, since the LSRp is indicative of the intensity of grazing adopted, where the higher intensity results in fewer residual leaf blades and thus a smaller amount of leaves under senescence in the following rest period.

There was high LSRp for intensive management (Table 4) even maintaining the same residual height of conventional management. This high LSRp can be attributed to the leaf area index (LAI) of the pasture, which was higher in the intensive management (4.84) than in the conventional one (4.57), due to fertilizer applied in the former, which promoted greater production of leaf blades, and even with similar grazing intensity these remnants remained on the pasture after grazing and, shortly after, started senescing.

The greater light distribution over the canopy, delaying the onset of senescence, with better optimization of the light use for photochemical reactions due to less cloudiness (Table 1), with higher direct light radiation during the dry period, were factors that contributed to lower LSRp in conventional management (Candido et al. 2005). It is worth mentioning the occurrence of a change in the LSRp pattern of intensive, moderate and light management from the rainy season to the dry season under irrigation. There was LSRp reduction when the period of year changed, probably due to the better light use throughout the canopy, reducing the aging process through mutual shading. The LSRp stability in between periods of the year in conventional management due to the higher grazing intensity, i.e., the lower grazing intensity (high residual height) and a moderate fertilization promote severe forage losses by senescence of leaves not grazed along the years.

The conventional management had higher $(\mathrm{P}<0.05)$ senescence rate after expansion of the first leaf produced during regrowth (LSRp) compared with other cropping systems (Table 4). The LSRa is the senescence of leaves formed from the first fully expanded leaf during the rest period and it is indicative of the adjustment of defoliation frequency to the canopy physiology, as a pasture managed for high use efficiency of forage produced should prevent leaf senescence formed in the regrowth, i.e., LSRa must be equal or near to zero. Thus, the greater rest period needed to reach 95\% IPAR (about 33 days on the average of all cycles) in the conventional management contributed to the greater LSRa. Higher LSRa $(\mathrm{P}<0.05)$ was also observed during the rainy season, compared with the dry season under irrigation. It was found that with increased cloudiness (higher in the rainy season and lower during the dry season under irrigation), regardless of the management employed, there is reduction of leaf blade loss by senescence $(\mathrm{P}<0.05)$ caused by the regrowth in the dry period under irrigation compared with the rainy season.

As in the LSRe, conventional management showed the highest $(\mathrm{P}<0.05)$ total leaf senescence rate (TSR), with 1.41 $\mathrm{cm} /$ tiller.day against $1.10,1.13$ and $1.01 \mathrm{~cm} /$ tiller.day for intensive, light and moderate management, respectively (Table 4). This greater loss of forage is due to the longer rest period observed in this management (33 days). Leaf senescence is a natural process that characterizes the last life phase of a leaf. After full expansion of the first leaves begins the senescence process, whose intensity is enhanced progressively with prolongation of the rest period and with increase in leaf area index due to the natural shading of leaves located at the lower canopy.

Leaf senescence contributes to the process of nutrient recycling in grassland ecosystem (Cecato et al., 2001), through the mineralization of litter mainly in the soil upper layers. Accordingly, pastures grazed without fertilization, especially at a lower grazing intensity, may contribute to the higher litter volume, which can reduce the input of chemical nutrients in pasture over time (Senthilkumar et al., 1992; Cecato et al., 2001). 
There was interaction between management and periods of the year $(\mathrm{P}<0.05)$ on the TSR (Table 4); regardless of the treatment used, there was reduction in total leaf senescence when pasture was managed from the rainy season to dry season under irrigation, showing that in this period the amount of light is probably enough to some extent to achieve the lower-insertion leaves in the tiller, keeping its photosynthetic rate and thus prolonging the leaf lifespan until its natural death.

Leaf appearance rate (LAR) showed interaction between management levels and periods of the year $(\mathrm{P}<0.05)$. Over the rainy season intensive ( 0.29 leaves/day) and moderate (0.28 leaves/day) management had higher LAR and only the intensive management ( 0.38 leaves/day) in the dry season under irrigation (Table 5). The increased availability of nitrogen possibly strongly contributed to the higher LAR in the intensive and moderate management compared with other levels. When comparing only the management levels without $\mathrm{N}$ fertilization, there was lower LAR for conventional management in the rainy season, but similar throughout the dry season under irrigation. The first situation occurred at the expense of the greater intensity of defoliation occurring in this management, which compromises the LAR (Davies, 1974), demonstrating the need for photoassimilates after defoliation by leaf meristems. In the second situation, the effect of greater grazing intensity was offset in the conventional management by the higher temperature during the dry period.

The LAR responds immediately to any change in temperature perceived by the apical meristem (Stoddart et al., 1986). Such responses are positive when a pasture is subjected to high temperatures $\left(32-37{ }^{\circ} \mathrm{C}\right)$. It is also important to emphasize that in management intensities with high $\mathrm{N}$ availability and $12.9 \mathrm{~cm}$ residual height, the change of the rainy season to dry season under irrigation causes increased LAR and consequently, increased production of tillers (2591 tillers $/ \mathrm{m}^{2}$ during the rainy season, against 5548 tillers $/ \mathrm{m}^{2}$ in the dry season under irrigation), considering that there is the emergence of a new phytomer on each leaf formed on a stem, i.e., there is generation of a new axillary bud that originates a new tiller when photostimulated. Contrary to this trend, pastures managed without fertilizer and with $21.7 \mathrm{~cm}$ residual height showed reduction in LAR from the rainy season to the dry season under irrigation. This fact can be explained by the delay in the onset of leaves above the sheaths, due to the increase of the sheaths in successive leaves (Duru \& Ducrocq, 2000) through the process of plant growth.

There was interaction between management levels and periods of the year $(\mathrm{P}<0.05)$ compared with the phyllochron. The conventional management showed higher phyllochron during the rainy season (5.96 days/leaf) than the others (Table 5). In the dry season under irrigation, both conventional (5.64 days/leaf) and light (5.36 days/leaf) management levels showed the highest phyllochron. This situation stems from the lack of nitrogen fertilization, demonstrating that the availability of nutrients, especially nitrogen, is important for the continuous emission of leaves, an important pre-requisite for maintaining production in crop systems throughout the year. The higher phyllochron during the rainy season in the conventional management compared with the light one is mainly for the latter presenting higher residue with larger amount of remaining leaves from grazing. In situations of lower grazing intensities, the time between the formation two consecutive leaves on the tiller is shorter due to the larger amount of leaf blades capable of photosynthesis, thereby producing photoassimilates that are translocated for the production of new leaves.

Table 4 - Leaf senescence rate before, leaf senescence rate after and total leaf senescence rate in Tifton 85 bermudagrass pastures under rotational stocking with different management strategies

\begin{tabular}{|c|c|c|c|c|c|c|c|}
\hline \multirow{2}{*}{ Variables } & \multirow{2}{*}{$\begin{array}{c}\text { Periods of the } \\
\text { year }\end{array}$} & \multicolumn{4}{|c|}{ Managements } & \multirow{2}{*}{ Mean } & \multirow{2}{*}{$\mathrm{CV}(\%)$} \\
\hline & & Conventional & Intensive & Light & Moderate & & \\
\hline \multirow{2}{*}{$\begin{array}{l}\text { Leaf senescence rate before } \\
\text { (cm/tiller.day) }\end{array}$} & Rainy & $0.69 \mathrm{Ab}$ & $1.25 \mathrm{Aa}$ & $1.10 \mathrm{Aa}$ & $1.14 \mathrm{Aa}$ & 1.04 & \multirow[t]{2}{*}{36.6} \\
\hline & Dry & $0.67 \mathrm{Aa}$ & $0.50 \mathrm{Ba}$ & $0.58 \mathrm{Ba}$ & $0.65 \mathrm{Ba}$ & 0.60 & \\
\hline Mean & & 0.68 & 0.87 & 0.83 & 0.90 & & \\
\hline \multirow{2}{*}{$\begin{array}{l}\text { Leaf senescence rate after } \\
\text { (cm/tiller.day) }\end{array}$} & Rainy & $1.10 \mathrm{Aa}$ & $0.41 \mathrm{Abc}$ & $0.52 \mathrm{Ab}$ & $0.19 \mathrm{Ac}$ & 0.55 & \multirow[t]{2}{*}{56.7} \\
\hline & Dry & $0.39 \mathrm{Ba}$ & $0.035 \mathrm{Bb}$ & $0.065 \mathrm{Bb}$ & $0.043 \mathrm{Ab}$ & 0.13 & \\
\hline \multirow{2}{*}{$\begin{array}{l}\text { Total leaf senescence rate } \\
\text { (cm/tiller.day) }\end{array}$} & Rainy & $1.77 \mathrm{Aa}$ & $1.66 \mathrm{Aa}$ & $1.61 \mathrm{Aa}$ & $1.33 \mathrm{Aa}$ & 1.59 & \multirow[t]{2}{*}{44.0} \\
\hline & Dry & $1.06 \mathrm{Ba}$ & $0.53 \mathrm{Bb}$ & 0.64Bab & $0.70 \mathrm{Bab}$ & 0.73 & \\
\hline Mean & & 1.41 & 1.10 & 1.13 & 1.01 & & \\
\hline
\end{tabular}

CV - coefficient of variation.

Managements: Conventional - $10 \mathrm{~cm}$ residual height and no fertilization; Intensive - $10 \mathrm{~cm}$ residual height and $600 \mathrm{~kg}$ N/ha.year; Light - $20 \mathrm{~cm}$ residual height and no fertilization; Moderate $-20 \mathrm{~cm}$ residual height and $300 \mathrm{~kg}$ of $\mathrm{N} / \mathrm{ha}$.year.

Means followed by the same uppercase letters in columns or lowercase letters in rows do not differ significantly $(\mathrm{P}>0.05)$ by Tukey's test. 
In intensive management, there was reduction in the phyllochron from the rainy season (3.68 days/leaf) to the dry season under irrigation (2.83 days/leaf). This fact was influenced by the higher temperature: the greater amount of direct light during such period maximized by the higher nitrogen fertilization promoted in this management. In times of year with higher direct light intensity, there must be a strategy for grazing management, such as increased frequency of defoliation to maximize the fodder use efficiency, preventing forage losses by senescence, considering this lower range in the leaf production observed in this period of the year. There is reduction in the interval of appearance of two consecutive leaves on the tiller from the rainy season to the dry period under irrigation $(\mathrm{P}<0.05)$ in the intensive management. The better conditions of light and temperature in intensively managed pastures favor greater leaf appearance and less phyllochron, important factors in productivity and persistence of pastures.

There was a big difference between the leaf lifetime (LLT) of conventional management in the dry season under irrigation(31.6 days) compared with the intensive management (14.5 days; Table 5). This big difference of LLT between two management levels is due to the high contribution of nitrogen in intensive management (600 kg/ha year). By having low LAR, low tillering and absence of nitrogen, there was compensatory effect of the plant with higher LLT, essential to optimize leaf area index and, indeed, the use of light, keeping the canopy photosynthetic capacity. The LLT reduction in management intensities with greater availability of nutrients is due to higher renewal of plant tissues (Martuscello et al., 2005), considering the positive effect of $\mathrm{N}$ on the increased tissue flow in the canopy.

There was increased LLT from the rainy season to the dry season under irrigation $(\mathrm{P}<0.05)$ in the non-fertilized management levels, showing that the effect of abiotic factors, mainly temperature and luminosity, are essential to maintaining the leaf life. Moreover, in management levels with higher doses of nitrogen (intensive management), there is LLT reduction $(\mathrm{P}<0.05)$ from the rainy season to the dry season under irrigation due to increased tissue renewal, influenced by favorable environmental characteristics this time of year. We all know the importance of assessing the LLT to assist in the pasture management, which in case of pastures managed under rotational stocking helps establishing a grazing frequency that maximizes the forage use efficiency, mainly by reducing forage losses by senescence. From this perspective, in more fertilized management types with greater defoliation intensity, grazing frequency must be higher to prevent forage losses by senescence and to prevent processes that hinder the forage consumption, such as reduced leaf/stem ratio. In management with moderate fertilization and lower defoliation intensity, this frequency should become a little lower. In non-fertilized pastures, more severe defoliation intensity makes use of a lower grazing frequency than in pastures maintained at lower defoliation intensity, since in the absence of fertilization, the tissue flow becomes slower, and a greater amount of remaining leaf blades from pasture aids the process of formation of new leaves by increased regrowth capacity compared with management systems with greater defoliation intensity.

Both the forage production rate (FPR) and the forage accumulation rate (FAR) showed interaction between management levels and periods of the year (Table 6), with higher production (181.6 kg DM/ha.day) and accumulation (161.3 kg DM/ha.day) observed in the intensive management during the dry season under irrigation. These values result from higher rates of biomass flow (LER, SER and TSR),

Table 5 - Leaf appearance rate, phyllochron and leaf lifespan in Tifton 85 bermudagrass pastures under rotational stocking with different management strategies

\begin{tabular}{|c|c|c|c|c|c|c|c|}
\hline \multirow{2}{*}{ Variables } & \multirow{2}{*}{$\begin{array}{c}\text { Periods of the } \\
\text { year }\end{array}$} & \multicolumn{4}{|c|}{ Managements } & \multirow{2}{*}{ Mean } & \multirow{2}{*}{$\mathrm{CV}(\%$} \\
\hline & & Conventional & Intensive & Light & Moderate & & \\
\hline \multirow{2}{*}{$\begin{array}{l}\text { Leaf appearance rate } \\
\text { (leaf/day) }\end{array}$} & Rainy & $0.17 \mathrm{Ac}$ & $0.29 \mathrm{Ba}$ & $0.22 \mathrm{Ab}$ & $0.28 \mathrm{Aa}$ & 0.24 & \multirow[t]{2}{*}{26.9} \\
\hline & Dry & $0.19 \mathrm{Ac}$ & $0.38 \mathrm{Aa}$ & $0.20 \mathrm{Bc}$ & $0.31 \mathrm{Ab}$ & 0.27 & \\
\hline Mean & & 0.18 & 0.34 & 0.21 & 0.30 & & \\
\hline \multirow{2}{*}{$\begin{array}{l}\text { Phyllochron } \\
\text { (days/leaf) }\end{array}$} & Rainy & $6.27 \mathrm{Aa}$ & $3.68 \mathrm{Ac}$ & $4.95 \mathrm{Ab}$ & $3.85 \mathrm{Ac}$ & 4.69 & \multirow[t]{2}{*}{26.8} \\
\hline & Dry & $5.64 \mathrm{Aa}$ & $2.83 \mathrm{Bc}$ & 5.36Aa & $3.33 \mathrm{Abc}$ & 4.30 & \\
\hline Mean & & 5.96 & 3.26 & 5.16 & 3.59 & & \\
\hline \multirow{2}{*}{$\begin{array}{l}\text { Leaf lifespan } \\
\text { (days) }\end{array}$} & Rainy & $30.0 \mathrm{Ba}$ & $17.5 \mathrm{Ac}$ & $26.0 \mathrm{Bb}$ & $18.0 \mathrm{Ac}$ & 22.8 & \multirow[t]{2}{*}{28.0} \\
\hline & Dry & $31.6 \mathrm{Aa}$ & $14.5 \mathrm{Bd}$ & $29.0 \mathrm{Ab}$ & $18.0 \mathrm{Ac}$ & 23.3 & \\
\hline Mean & & 30.8 & 16.0 & 27.6 & 18.0 & & \\
\hline
\end{tabular}

$\mathrm{CV}$ - coefficient of variation.

Managements: Conventional $-10 \mathrm{~cm}$ residual height and no fertilization; Intensive - $10 \mathrm{~cm}$ residual height and $600 \mathrm{~kg}$ N/ha.year; Light - $20 \mathrm{~cm}$ residual height and no fertilization; Moderate $-20 \mathrm{~cm}$ residual height and $300 \mathrm{~kg}$ of N/ha.year.

Means followed by the same uppercase letters in columns or lowercase letters in rows do not differ significantly $(\mathrm{P}>0.05)$ by Tukey's test. 
Table 6 - Forage production rate and forage accumulation rate in Tifton 85 bermudagrass pastures under rotational stocking with different management strategies

\begin{tabular}{lcccccc}
\hline \multirow{2}{*}{ Variables } & \multirow{2}{*}{$\begin{array}{c}\text { Periods of the } \\
\text { year }\end{array}$} & \multicolumn{4}{c}{ Managements } & \multirow{2}{*}{ Mean } \\
\cline { 3 - 6 } Conventional & Intensive & Light & Moderate & \\
\hline Forage production rate & Rainy & $114.6 \mathrm{Aab}$ & $135.1 \mathrm{Bab}$ & $102.0 \mathrm{Ab}$ & $149.0 \mathrm{Aa}$ & 125.2 \\
(kg/ha.day of DM) & Dry & $103.0 \mathrm{Ab}$ & $181.6 \mathrm{Aa}$ & $107.4 \mathrm{Ac}$ & $154.6 \mathrm{Aa}$ & 136.5 \\
Mean & & 108.8 & 158.0 & 107.4 & 151.8 & 70.4 \\
Forage accumulation rate & Rainy & $73.0 \mathrm{Ab}$ & $106.1 \mathrm{Ba}$ & $55.1 \mathrm{Ab}$ & $98.2 \mathrm{Aa}$ & 83.1 \\
(kg/ha.day of DM) & Dry & $80.1 \mathrm{Ab}$ & $161.3 \mathrm{Aa}$ & $77.0 \mathrm{Ab}$ & $126.0 \mathrm{Aa}$ & 111.1 \\
Mean & & 30.8 & 16.0 & 27.6 & 18.0 & 86.6 \\
\hline
\end{tabular}

DM - dry matter; CV - coefficient of variation.

Managements: Conventional - $10 \mathrm{~cm}$ residual height and no fertilization; Intensive - $10 \mathrm{~cm}$ residual height and $600 \mathrm{~kg}$ N/ha.year; Light - $20 \mathrm{~cm}$ residual height and no fertilization; Moderate $-20 \mathrm{~cm}$ residual height and $300 \mathrm{~kg}$ of $\mathrm{N} / \mathrm{ha}$.year.

Means followed by the same uppercase letters in columns or lowercase letters in rows do not differ significantly (P $>0.05)$ by Tukey's test.

promoted due to the higher nitrogen fertilization, associated with high tiller density (5809 tillers $/ \mathrm{m}^{2}$ compared with 3654,3453 and 4185 tillers $/ \mathrm{m}^{2}$ in conventional, light and moderate management, respectively) observed in this management.

There was increase of $25.3 \% \mathrm{FPR}$ and $34.2 \%$ FAR from the rainy season to the dry season under irrigation in the intensive management. This arises from the lower cloudiness, which denotes greater amount of direct sunlight this time of year, favoring the maximization of metabolic processes that form compounds intended for plant tissues, favored by higher leaf weight, given the low leaf area specific of leaves that develop in environments of higher luminosity. There was increased FPR and FAR $(\mathrm{P}<0.05)$ from the rainy season to the dry season under irrigation only in the intensive management, most likely due to a combination of higher fertilization in the management that promoted especially greater tillering with longer photoperiod and radiation observed in the dry season under irrigation, essential for the pasture growth.

\section{Conclusions}

The leaf and stem elongation rates are changed according to the level of intensification of pasture management used and with the change of time of year. Senescence rates are high when managed during the rainy season. Nitrogen fertilization in Tifton 85 bermudagrass pasture decreases the leaf lifespan and accelerates the appearance of new leaves. Using the moderate management, characterized by a residual height of 22.9 and nitrogen dose equivalent to $300 \mathrm{~kg} \mathrm{~N} /$ ha.year during the rainy season and adopting intensive management during the dry season under irrigation, characterized by a high residual of $12.9 \mathrm{~cm}$ and nitrogen rate equivalent to $600 \mathrm{~kg} \mathrm{~N} /$ ha.year, show better combination of grassland exploitation in northern Ceará.

\section{References}

BARBOSA, R.A.; NASCIMENTO JR., D.; EUCLIDES, V.P.B. et al. Capim-tanzânia submetido a combinações entre intensidade e freqüência de pastejo. Pesquisa Agropecuária Brasileira, v.42, n.3, p.329-340, 2007.

BRAGA, G.J.; MELLO, A.C.L.; PEDREIRA, C.G.S. et al. Fotossíntese e taxa diária de produção de forragem em pastagens de capim-tanzânia sob lotação intermitente. Pesquisa Agropecuária Brasileira, v.44, n.1, p.84-91, 2009.

BULLOCK, J.M. Plant competition and population dynamics. In: HODGSON, J.; ILLIUS, A.W. (Eds.). The ecology and management of grazing systems. Wallingford: $\mathrm{CAB}$ International, 1996. p.69-100.

BUXTON, D.R.; FALES, S.L. Plant environment and quality. In: FAHEY JUNIOR, G.C. (Ed.). Forage quality, evaluation and utilization. Lincoln: University of Nebraska, 1994. p.155-199.

CABRAL, R.C. Evapotranspiração de referência de Hargreaves (1974) corrigida pelo método de Penman-Montheith/FAO (1991) para o estado do Ceará. 2000. 83f. Dissertação (Mestrado em Engenharia Agrícola) - Universidade Federal do Ceará, Fortaleza.

CÂNDIDO, M.J.D. Morfofisiologia e crescimento do dossel e desempenho animal em Panicum maximum cv. Mombaça sob lotação intermitente com três períodos de descanso. 2003. $134 \mathrm{f}$. Tese (Doutorado em Zootecnia) - Universidade Federal de Viçosa, Viçosa, MG

CÂNDIDO, M.J.D.; GOMIDE, C.A.M.; ALEXANDRINO, E. et al. Morfofisiologia do dossel de Panicum maximum cv. Mombaça sob lotação intermitente com três períodos de descanso. Revista Brasileira de Zootecnia, v.34, n.2, p.338-347, 2005.

CÂNDIDO, M.J.D.; SILVA, R.G.; NEIVA, J.N.M. et al. Fluxo de biomassa em capim-tanzânia pastejados por ovinos sob três períodos de descanso. Revista Brasileira de Zootecnia, v.35, n.6, p.2234-2242, 2006.

CASTRO, C.R.T.; GARCIA, R.; CARVALHO, M.M. et al. Produção forrageira de gramíneas cultivadas sob luminosidade reduzida. Revista Brasileira de Zootecnia, v.28, n.5, p.919-927, 1999.

CECATO, U.; CASTRO, C.R.C.; CANTO, M.W. et al. Perdas de forragem em capim-tanzânia (Panicum maximum Jacq cv Tanzânia-1) manejado sob diferentes alturas sob pastejo. Revista Brasileira de Zootecnia, v.30, n.2, p.295-301, 2001.

COMISSÃO DE FERTILIDADE DO SOLO DE MINAS GERAIS - CFSEMG. Recomendações para o uso de corretivos e fertilizantes em Minas gerais. $5^{a}$ Aproximação. Viçosa, MG, 1999. 359p.

CHAPMAN, D.; LEMAIRE, G. Morphogenetic and structural determinants of plant regrowth after defoliation. In: INTERNATIONAL GRASSLAND CONGRESS, 17., 1993, Palmerston North. Proceedings... Palmerston Nort, 1993. p.95-104.

CORSI, M.; MARTHA JÚNIOR, G.B.; NASCIMENTO JÚNIOR, D. et al. Impact of grazing management on productivity of 
tropical grasslands. In: INTERNATIONAL GRASSLAND CONGRESS, 19., 2001, Piracicaba. Proceedings... Piracicaba, 2001. p.801-806.

CUTRIM JUNIOR, J.A.A.; CÂNDIDO, M.J.D.; VALENTE, B.S.M. et al. Fluxo de biomassa em capim-tanzânia sob três frequências de desfolhação e dois resíduos pós-pastejo. Revista Brasileira de Saúde e Produção Animal, v.11, n.3, p.618-629, 2010.

DA SILVA, S.C. Fundamentos para o manejo do pastejo de plantas forrageiras dos gêneros Brachiaria e Panicum. In: SIMPÓSIO SOBRE MANEJO ESTRATÉGICO DA PASTAGEM, 2., 2004, Viçosa, MG. Anais... Viçosa, MG: UFV, 2004. p.347-385.

DAVIES, A. Leaf tissue remaining after cutting and regrowth in perennial ryegrass. Journal of Agricultural Science, v.82, p.165-172, 1974.

DAVIS,M.H.;SIMMONS, S.R.Far-redlightreflected fromneighbouring vegetation promotes shoot elongation and accelerates flowering in spring barley plants. Plant Cell Environments, v.17, n.7, p.829-836, 1994.

DEREGIBUS, V.A.; SANCHEZ, R.A.; CASAL, J.J. et al. Tillering responses to enrichment of red light beneath the canopy in a humid natural grassland. Journal Applied Ecology, v.22, p.199-206, 1985.

DURU, M.; DUCROCQ, H. Growth and senescence of the successive leaves on a Cocksfoot tiller. Ontogenic development and effect of temperature. Annals of Botany, v.85, p.635-643, 2000.

GASTAL, F.; NELSON, C.J. Nitrogen use within the growing leaf blade of tall fescue. Plant Physiology, v.105, p.191-197, 1994.

GOMIDE, C.A.M.; GOMIDE, J.A.; MARTINEZ Y HUAMAN, C.A. et al. Fotossíntese, reservas orgânicas e rebrota do Capim-Mombaça (Panicum maximum Jacq.) sob diferentes intensidades de desfolha do perfilho principal. Revista Brasileira de Zootecnia, v.31, n.6, p.2165-2175, 2002.

HODGSON, J. Grazing management: science into practice. Essex: Longman Scientific e Technical, 1990. 203p.

LEMAIRE, G.; CHAPMAN, D. Tissue flows in grazed plant communities. In: HODGSON, J.; ILLIUS, A.W. (Eds.) The ecology and management of grazing systems. Wallingford: CAB International, 1996. p.3-36.

MARTHA JÚNIOR, G.B.; VILELA, L.; BARIONI, L.G. et al. Manejo da adubação nitrogenada em pastagens. In: SIMPÓSIO SOBRE MANEJO DA PASTAGEM, 24., 2007, Piracicaba. Anais... Piracicaba: FEALQ, 2007. p.39-74.
MARTUSCELLO, J.A.; FONSECA, D.M.; NASCIMENTO JÚNIOR, D. et al. Características morfogênicas e estruturais do capim-xaraés submetido à adubação nitrogenada e desfolhação. Revista Brasileira de Zootecnia, v.34, n.5, p.1475-1482, 2005.

MOREIRA, L.M. Características estruturais do pasto, composição química e desempenho de novilhos em pastagem de Brachiaria decumbens cv. basilisk adubada com nitrogênio. 2000. 132f. Tese (Doutorado em Zootecnia) - Universidade Federal de Viçosa, Viçosa, MG.

POMPEU, R.C.F.F.; CÂNDIDO, M.J.D.; LOPES M.N. et al. Características morfofisiológicas do capim-aruana sob diferentes doses de nitrogênio. Revista Brasileira de Saúde e Produção Animal, v.11, n.4, p.1187-1210, 2010.

SANTOS, HG; JACOMINE, PKT; ANJOS, LHC. et al. Sistema brasileiro de classificação de solos. 2.ed. Rio de Janeiro: Embrapa Solos, 2006. 306p.

SANTOS, M.E.R. Ajustes no manejo do pastejo em pastagens adubadas. Enciclopédia Biosfera, v.6, n.11, p.1, 2010.

SENTHILKUMAR, K.; UDAYAN, K.; MANIAN, S. Rate of litter decomposition in a tropical grassland dominated by Cibopogon caesius in Southen India. Tropical Grassland, v.26, p.235-242, 1992.

SKINNER, R.H.; NELSON, C.J. Elongation of the grass leaf and its relationship to the phyllochron. Crop Science, v.35, p.4-10, 1995.

STODDART J.L.; THOMAS H.; LLOYD E.J. et al. The use of a temperature-profiled position transducer for the study of lowtemperature growth in Gramineae. Planta, v.167, p.359-363, 1986.

TAIZ, L.; ZEIGER, E. Fisiologia vegetal. 3.ed. Porto Alegre: Artmed, 2004. 722p.

UEBELE, M.C. Padrões demográficos de perfilhamento e produção de forragem em pastos de capim Mombaça submetidos a regimes de lotação intermitente. 2002. 83f. Dissertação (Mestrado em Ciência Animal e Pastagem) - Escola Superior de Agricultura "Luiz de Queiroz", Piracicaba.

WOLEDGE, J. The photosynthesis of ryegrass leaves grown in a simulated sward. Annals of Applied Biology, v.73, p.229-237, 1973.

WOLEDGE, J. The effects of shading and cutting treatments on the photosynthetic rate of ryegrass leaves. Annals of Botany, v.41, p.1279-1286, 1977. 